\title{
Redox transfer at subduction zones: insights from Fe isotopes in the Mariana forearc
}

\author{
B. Debret ${ }^{1 *}$, C.D.J. Reekie ${ }^{2}$, N. Mattielli ${ }^{3}$, H. Beunon ${ }^{3}$, \\ B. Ménez ${ }^{1}$, I.P. Savov ${ }^{4}$, H.M. Williams ${ }^{2}$
}

Abstract

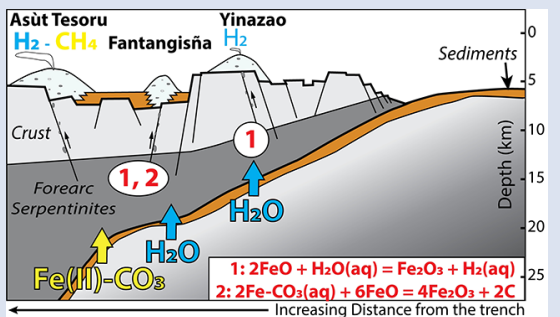

Subduction zones are active sites of chemical exchange between the Earth's surface and deep interior and play a fundamental role in regulating planet habitability. However, the mechanisms by which redox sensitive elements (e.g., iron, carbon and sulfur) are cycled during subduction remains unclear. Here we use Fe stable isotopes $\left(\delta^{56} \mathrm{Fe}\right)$, which are sensitive to redox-related processes, to examine forearc serpentinite clasts recovered from deep sea drilling of mud volcanoes formed above the Mariana subduction zone in the Western Pacific. We show that serpentinisation of the forearc by slab-derived fluids produces dramatic $\delta^{56} \mathrm{Fe}$ variation. Unexpected negative correlations between serpentinite bulk $\delta^{56} \mathrm{Fe}$, fluid-mobile element concentrations (e.g., B, As) and $\mathrm{Fe}^{3+} / \Sigma \mathrm{Fe}$ suggest a concomitant oxidation of the mantle wedge through the transfer of isotopically light iron by slab-derived fluids. This process must reflect the transfer of either sulfate- or carbonate-bearing fluids that preferentially complex isotopically light Fe.

Received 15 August 2019 | Accepted 10 December 2019 | Published 31 January 2020

\section{Introduction}

Subduction zones regulate chemical exchange between the Earth's surface and interior, modulating the long term cycling of redox sensitive elements such as iron, carbon and sulfur (Evans, 2012). Recent iron isotope studies $\left(\delta^{56} \mathrm{Fe}\right)$ have shown that iron, which was previously considered to be insoluble, can be mobilised in slab-derived fluids by complexation with chloride and/or oxidising ligands (e.g., $\mathrm{Fe}(\mathrm{II})-\mathrm{CO}_{3}$ or $\mathrm{Fe}(\mathrm{II})-\mathrm{SO}_{4}$; Debret et al., 2016, 2018). Importantly, these complexes preferentially concentrate light (low) $\delta^{56} \mathrm{Fe}$, driving stable isotope fractionation (Debret et al., 2016, 2018). These findings concur with the high $\mathrm{Fe}^{3+} / \Sigma \mathrm{Fe}$ (Kelley and Cottrell, 2009) and light $\delta^{56} \mathrm{Fe}$ (Nebel et al., 2015) of arc lavas relative to mid-ocean ridge basalts, although the origin of light $\delta^{56} \mathrm{Fe}$ in arc lavas remains an active research frontier. Iron stable isotopes are therefore a potentially powerful tool to track the mobility of iron and the fate of oxidised fluids across subduction zones. However, questions remain as to whether iron is sufficiently concentrated in slab-derived fluids to influence the $\delta^{56} \mathrm{Fe}$ of the sub-arc mantle and if so, do links between the oxidation state and the $\delta^{56} \mathrm{Fe}$ of mantle wedge peridotites exist?

The transfer of redox sensitive elements across subduction zones involves complex and multi-stage processes (Nebel et al., 2015). For example, both the oxidation state and isotope signature of mantle wedge peridotites are likely to be influenced by existing heterogeneities prior to subduction (Williams et al., 2004), as well as by later metasomatism by slab-derived fluids and/or melts (Huang et al., 2019) and/or retrograde processes linked to rock exhumation (Li et al., 2016). Despite this, Turner et al. (2018) recently showed that the unusually light $\delta^{56} \mathrm{Fe}$ values (down to $-0.31 \%$ o) of some sub-arc mantle xenoliths were too fractionated to have been caused solely by partial melting. They observed correlations between $\delta^{56} \mathrm{Fe}$ with ${ }^{206} \mathrm{~Pb} / 204 \mathrm{~Pb}$ and $\mathrm{U} / \mathrm{Th}$, tracers of fluid-related processes, and suggested that sample $\delta^{56} \mathrm{Fe}$ was modified by reaction with low $\delta^{56} \mathrm{Fe}$ slab fluids. Similar conclusions were reached by Debret et al. (2018) who analysed metamorphic gem olivines in veins from the sub-arc mantle of the Kohistan-Ladakh arc. The vein-forming minerals are interpreted to have crystallised from fluids that migrated through the forearc mantle, and they display light $\delta^{56} \mathrm{Fe}(-0.06$ to $-0.36 \%$ o) relative to typical mantle olivine ( $+0.01 \%$; Sossi et al., 2015). These results suggest a strong coupling between slab-derived fluids and the $\delta^{56} \mathrm{Fe}$ composition of the mantle wedge.

To test this idea we carried out a $\delta^{56} \mathrm{Fe}$ study of serpentinite clasts from the Mariana forearc. The Mariana forearc is the only place in the world where actively metasomatised forearc can be sampled (Savov et al., 2007; Fryer et al., 2018). It belongs to a non-accretionary subduction system, spreading from near Tokyo (Japan) to beyond Guam (U.S.A.) and involves the subduction of the Mesozoic Pacific plate below the Philippine

\footnotetext{
1. Université de Paris, Institut de physique du globe de Paris, CNRS UMR 7154, 1 rue Jussieu, 75005 Paris, France

2. Department of Earth Sciences, University of Cambridge, Downing Street, Cambridge CB2 3EQ, United Kingdom

3. Laboratoire G-Time, DGES, Université Libre de Bruxelles, ULB, CP 160/02, 1050 Brussels, Belgium

4. School of Earth and Environment, University of Leeds, Leeds, LS2 9JT, United Kingdom

Corresponding author (email: debret@ipgp.fr)
} 

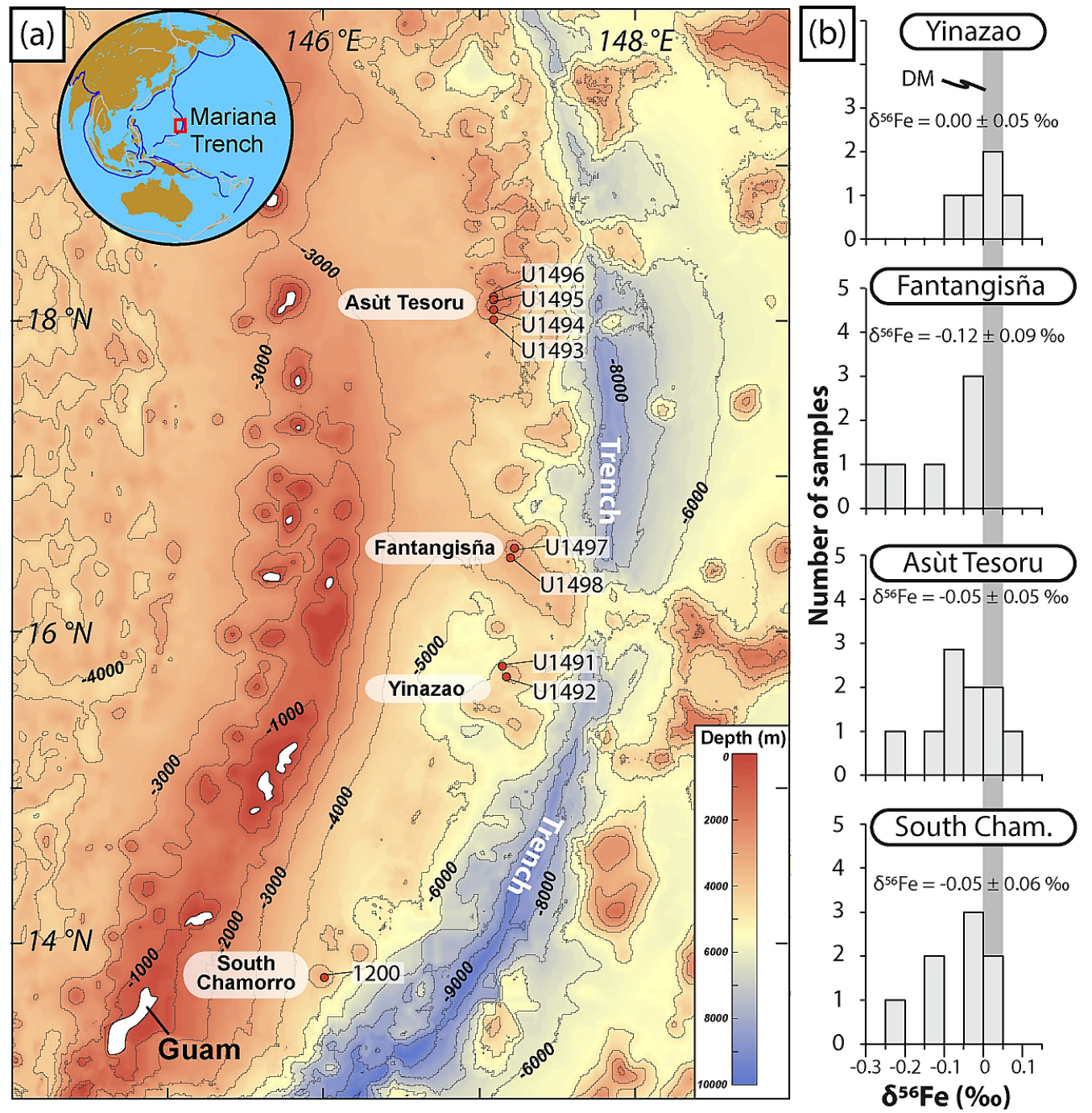

Figure 1 Distribution of $\delta^{56} \mathrm{Fe}$ values in forearc serpentinites. (a) Bathymetry map of the Mariana subduction system showing the locations of the mud volcanoes drilled during IODP Expedition 366 and the ODP Leg 195. Hole locations are indicated in red circles. (b) Iron isotope compositions of bulk ultramafic clasts from the Mariana forearc, organized according to the distance from the trench. DM: Depleted Mantle (Craddock et al., 2013).

Sea plate (Fig. 1). Here, fluids released from the subducting slab bring metasomatised forearc rocks to the surface and erupt as mud volcanoes. These rocks provide a direct window into $\delta^{56} \mathrm{Fe}$ and redox exchanges between the subducted slab and the forearc mantle at various depths. Our study focuses on serpentinised forearc peridotite clasts recovered during the International Oceanic Discovery Program (IODP) Expedition 366 by drilling three mud volcanoes: Yinazao, Fantangisña and Asùt Tesoru, located at increasing distance from the trench (Table S-1, Fig. 1).

\section{Sample Selection}

The studied clasts have been petrographically and geochemically characterised by Debret et al. (2019) and Fryer et al. (2018). They provide a record of deep forearc mantle serpentinisation by slab-derived fluids. Lizardite-bearing serpentinites (Liz-serpentinites) display variable degrees of serpentinisation (from 30 to $100 \%$ ) and are primarily composed of low temperature brown serpentine (i.e. lizardite and/or chrysotile) and Fe-rich brucite assemblages forming mesh and bastite textures after olivine and orthopyroxene, respectively. These samples represent the first stage of forearc mantle wedge hydration at low temperature $\left(180-230{ }^{\circ} \mathrm{C}\right.$, based on oxygen isotope estimates) and shallow depths $(<13 \mathrm{~km}$; Debret et al., 2019). Antigorite-bearing serpentinites (Atg/Liz- and Atg-serpentinites) are highly serpentinised ( $100 \%)$ and show progressive replacement of lizardite-bearing textures (i.e. mesh and bastite) by antigorite, magnetite and Fe-poor brucite. Oxygen isotope measurements show that the recrystallisation of lizardite to antigorite occurs at temperatures ranging from $200-250{ }^{\circ} \mathrm{C}$ to $320-410{ }^{\circ} \mathrm{C}$ (Debret et al., 2019), consistent with thermodynamic predictions (Evans, 2004) and antigorite crystallisation temperature estimates derived from meta-ophiolite serpentinites (Schwartz et al., 2013). This provides evidence for the formation of these samples during the progressive burial and hydration of the forearc mantle at depths ranging from 13 to $18 \mathrm{~km}$. The recrystallisation of lizardite to antigorite is accompanied by a decrease in Cs, $\mathrm{Li}$ and $\mathrm{Sr}$, and an increase in As and Sb concentrations in the bulk clasts, whereas B concentrations are relatively constant (Debret et al., 2019). The forearc wedge also experienced late stage serpentinisation at low temperature $\left(<180{ }^{\circ} \mathrm{C}\right)$ during clast exhumation which is characterised by the crystallisation of "blue" serpentine and sulfides (blue-serpentinite; Debret et al., 2019). Where present, this late serpentinisation stage largely replaces former textures, i.e. serpentine or mantle minerals, and results in a flattening of rare earth element (REE) spectra and an increase in bulk serpentinite $\mathrm{Zn}$ concentration. In order to constrain the impact of such late retrogression stages on the Fe redox state and isotope composition of forearc peridotites, 
we analysed a suite of these blue-serpentinites. Finally, we tested the chemical and Fe-isotope variability of serpentinised clasts along the Mariana forearc by analysing a suite of ultramafic clasts recovered from South Chamorro, one of the most distant mud volcanoes from the trench located at the extreme south of the Mariana subduction, during the Ocean Drilling Program (ODP) Leg 195 (Fig. 1).

\section{Results}

The $\delta^{56} \mathrm{Fe}$ and $\mathrm{FeO}$ methods and data (samples and standards) are provided in the Supplementary Information. The Mariana ultramafic clasts display large variations in $\mathrm{Fe}^{3+} / \Sigma \mathrm{Fe}$ $(0.24-0.67)$ and $\delta^{56} \mathrm{Fe}(-0.26 \pm 0.06,2 \mathrm{~s} . \mathrm{d}$., to $+0.09 \pm 0.02 \%$; Table S-2) with a light mean $\delta^{56} \mathrm{Fe}$ of $-0.06 \pm 0.03 \%$ relative to that of the depleted mantle, as estimated from abyssal peridotites (+0.025 $\pm 0.025 \%$; Craddock et al., 2013). No systematic variations in $\mathrm{Fe}^{3+} / \Sigma \mathrm{Fe}$ and $\delta^{56} \mathrm{Fe}$ values were observed with increasing distance to the trench or mud volcano location (Fig. 1). In contrast, there is a progressive increase in $\mathrm{Fe}^{3+} / \Sigma \mathrm{Fe}$ and decrease in $\delta^{56} \mathrm{Fe}$ from Liz- serpentinites $\left(\mathrm{Fe}^{3+} / \Sigma \mathrm{Fe}=0.24-0.37 ; \delta^{56} \mathrm{Fe}=-0.02 \pm 0.12 \%\right.$ o $)$ to Atg/Liz$\left(\mathrm{Fe}^{3+} / \Sigma \mathrm{Fe}=0.33-0.59 ; \delta^{56} \mathrm{Fe}=-0.07 \pm 0.09 \%\right)$ and Atg$\left(\mathrm{Fe}^{3+} / \Sigma \mathrm{Fe}=0.51-0.67 ; \delta^{56} \mathrm{Fe}=-0.12 \pm 0.07 \%\right.$ o $)$ serpentinites These variations are broadly correlated with increasing bulk rock fluid-mobile element (FME) concentrations (Fig. 2). In contrast, blue-serpentinites display a large range of $\mathrm{Fe}^{3+} / \Sigma \mathrm{Fe}$ $(0.33-0.77)$ with depleted mantle-like $\delta^{56} \mathrm{Fe}(-0.01 \pm 0.03$ $\%$ o) and correlations with FME concentrations are absent (Table S-2, Fig. S-1a-c).

\section{Discussion}

The low $\delta^{56} \mathrm{Fe}$ signatures of antigorite-bearing clasts agree with our prediction that isotopically light Fe is mobilised in slab fluids (e.g., Debret et al., 2016, 2018). However, before assigning all Fe isotope variability to fluids, several processes must be considered: (1) pre-existing Fe isotope mantle heterogeneities prior to the forearc serpentinisation and (2) the mobility of Fe during late serpentinisation stages accompanying clast exhumation (e.g., blue-serpentine crystallisation). The influence of kinetic effects, related to the preferential mobility of isotopically light species during fluid/rock interactions or diffusive processes, can be ruled out as the direction of diffusive transport from solid (Fe-rich) to fluid (Fe-poor) would result in enrichment in isotopically heavy Fe in the solid, which would generate positive covariations between $\delta^{56} \mathrm{Fe}$ and $\mathrm{Fe}^{3+} / \Sigma \mathrm{Fe}$ in the studied samples, which are not observed (Fig. 2c).

Forearc mantle wedge peridotites are former sub-arc peridotites that underwent extensive partial melting before being dragged into the forearc by mantle convection (Parkinson and Pearce, 1998). In serpentinised peridotites, protolith fertility is better assessed by $\mathrm{Al}_{2} \mathrm{O}_{3} / \mathrm{SiO}_{2}$ ratio rather than $\mathrm{Al}_{2} \mathrm{O}_{3}$ contents (Niu, 2004). The Mariana ultramafic clasts display low $\mathrm{Al}_{2} \mathrm{O}_{3} / \mathrm{SiO}_{2}(<0.03)$ consistent with a refractory protolith, i.e. dunite or pyroxene-poor harzburgite. However, the studied samples also display a large range in $\delta^{56} \mathrm{Fe}$ relative to dunite-like reference materials (Table S-2) and no systematic variation between $\delta^{56} \mathrm{Fe}$ and $\mathrm{Al}_{2} \mathrm{O}_{3} / \mathrm{SiO}_{2}$ ratio are observed (Fig. S-2a). Similarly, previous studies have shown that high temperature metasomatic events (e.g., melt percolation) can lead to an enrichment in isotopically light Fe (Poitrasson et al., 2013). However, such processes also generate an increase in $\mathrm{FeO}$ and correlation between $\delta^{56} \mathrm{Fe}$ and $\mathrm{XMg}(=\mathrm{Mg} /[\mathrm{Mg}+$ Fe]) are not observed in the studied samples (Fig. S-2b). This
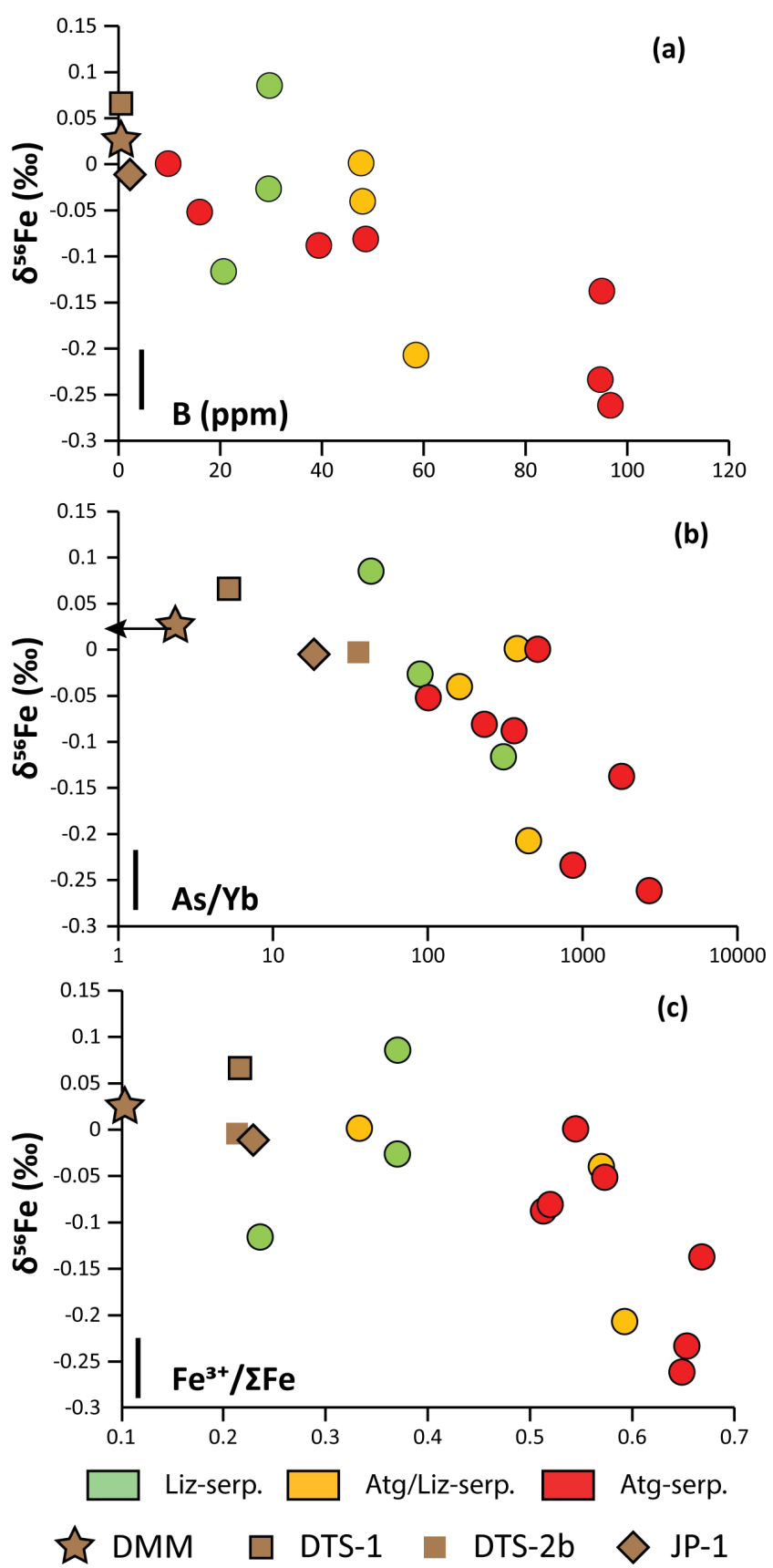

Figure 2 Plots of $\delta^{56} \mathrm{Fe}$ versus (a) B concentrations, (b) As/Yb and (c) $\mathrm{Fe}^{3+} / \Sigma \mathrm{Fe}$ ratios in Mariana ultramafic clasts. The black bar represents the $\mathrm{FeCl}$ standard reproducibility during analyses. DTS-1, DTS-2b, JP-1: dunite-like reference materials.

shows that the light $\delta^{56} \mathrm{Fe}$ of Mariana clasts are not controlled by pre-existing protolith heterogeneities and must have been generated by the mobilisation of Fe in fluids.

Late serpentinisation stages that overprint high temperature paragenesis are associated with exhumation of clasts and are characterised by blue-serpentine crystallisation and changes in trace element chemistry (Debret et al., 2019). However, despite strong enrichments in $\mathrm{Zn}$, blue-serpentinites display similar $\delta^{56} \mathrm{Fe}$ (from $-0.07 \%$ to $+0.05 \%$ ) to depleted mantle, dunite reference materials and abyssal peridotites (Fig. S-3). Similarly, no correlation between $\delta^{56} \mathrm{Fe}$ and indices of late processes, for example, seafloor carbonation (e.g., $\mathrm{Sr} / \mathrm{Yb}$ ) and/or blue-serpentine (e.g., Zn) crystallisation, are observed (Fig. S-3). This suggests that the Mariana forearc clasts preserved $\delta^{56} \mathrm{Fe}$ values acquired prior to exhumation. 
The light $\delta^{56} \mathrm{Fe}$ of our samples must therefore relate either to the loss or the addition of Fe during the serpentinisation of the forearc mantle at depth.

It is well established that forearc mantle serpentinisation by slab-derived fluids is accompanied with an increase in bulk rock FME concentrations (e.g., Savov et al., 2007). This enrichment has been attributed to the influx of slab-derived fluids in the forearc mantle at intermediate temperatures $\left(200-600{ }^{\circ} \mathrm{C}\right)$. In Figure $2 \mathrm{a}, \mathrm{b}$, the prograde Mariana ultramafic clasts (Liz-, Atg/Liz- and Atg-serpentinites) form a step array that extends from mantle-like to low $\delta^{56} \mathrm{Fe}$ values $(-0.26 \%$; this is accompanied with an increase in FME concentrations. In contrast, no correlation between $\delta^{56} \mathrm{Fe}$ and FME concentrations is observed in retrograde blue-serpentinites or abyssal serpentinites (Fig. S-1a,b). The light $\delta^{56} \mathrm{Fe}$ of the studied samples therefore must reflect the addition of isotopically light Fe by slab-derived fluids. Furthermore, this decrease in $\delta^{56} \mathrm{Fe}$ is associated with an increase in $\mathrm{Fe}^{3+} / \Sigma \mathrm{Fe}$ (Fig. 2c), which is opposed to isotope theory predicting that isotopically heavy Fe will be concentrated into $\mathrm{Fe}^{3+}$-bearing phases rather than $\mathrm{Fe}^{2+}$-bearing phases (Polyakov and Mineev, 2000). This observation thus rules out the direct transfer of $\mathrm{Fe}^{3+}$ by slab-derived fluids. Instead, it suggests a concomitant transfer of isotopically light $\mathrm{Fe}^{2+}$ complexed with an oxidising component (e.g. sulfate or carbonate) in slab-derived fluids. Both sulfate or carbonate complexes have the potential to modify both the Fe isotope signature and oxidation state of forearc serpentinites, despite the relatively low solubility of Fe in fluids (Debret et al., 2018). Although chlorine complexes (e.g., $\mathrm{Fe}(\mathrm{II}) \mathrm{Cl}_{2}$ ), also preferentially complex light Fe, they are inefficient oxidisers of $\mathrm{Fe}$, and thus an unlikely means of generating the observed relationships between $\delta^{56} \mathrm{Fe}$ and $\mathrm{Fe}^{3+} / \Sigma \mathrm{Fe}$ (Fig. 2c).

Differences in the stability fields of hydrous, carbon- and sulfur-bearing minerals mean that the compositions of fluid liberated from the subducting slab change progressively with depth. Because of the pronounced differences in $\delta^{56} \mathrm{Fe}$ between the Liz- and Atg-serpentinite clasts, it is important to identify the reactions responsible for the transfer of isotopically light and oxidised Fe to the mantle wedge. The serpentinisation of mantle peridotites through their interaction with water is commonly associated with the oxidation of ferrous $\mathrm{Fe}$, leading to a progressive increase of $\mathrm{Fe}^{3+} / \Sigma \mathrm{Fe}$ in the bulk rock and $\mathrm{H}_{2}$ production in the fluid phase through water reduction (Fig. 3):

$$
3 \mathrm{FeO}+\mathrm{H}_{2} \mathrm{O}_{(\mathrm{aq})}=\mathrm{Fe}_{3} \mathrm{O}_{4}+\mathrm{H}_{2(\mathrm{aq})}
$$

This process is expected to be efficient at the relatively low temperature of forearc serpentinisation (i.e. lower than 700 ${ }^{\circ} \mathrm{C}$; Frost and Ballhaus, 1998). It can explain why the Mariana ultramafic clasts have high $\mathrm{Fe}^{3+} / \Sigma \mathrm{Fe}$ ratios $(0.24-0.67)$ relative to mantle peridotites ( 0.1; Canil et al., 1994). However, no obvious correlations between bulk rock water content and Fe redox state or between bulk rock water content and $\delta^{56} \mathrm{Fe}$ are observed (Fig. S-4). Light $\delta^{56} \mathrm{Fe}$ are mainly observed in antigorite-bearing samples while lizardite-bearing serpentinite displays depleted mantle-like values (Fig. 2). This suggests a marked change in the composition of slab-derived fluids with depth, where the composition of fluids derived at greater depths preferentially mobilise Fe relative to fluids released at shallower levels. Fluids released during the early (shallow) stage of slab devolatilisation $(<13 \mathrm{~km}$ depth) are likely dominated by diagenetic processes and opal dehydration, whereas later (deeper) processes can include decarbonation and clay mineral decomposition reactions (Bebout, 2013 and references therein). Arsenic, Sb and light REE are preferentially enriched in fluids derived from sediment or metabasite decarbonation reactions (Bebout, 2013). The correlation between As/Yb and $\delta^{56} \mathrm{Fe}$ in ultramafic clasts (Fig. $2 \mathrm{~b}$ ) may therefore indicate light $\delta^{56} \mathrm{Fe}$ is transferred to the mantle wedge by carbonate complexes. The transfer of redox sensitive elements, such as carbon, can modify the redox state of the forearc mantle according to the reaction (Fig. 3):

$$
2 \mathrm{FeCO}_{3(\mathrm{aq})}+6 \mathrm{FeO}=4 \mathrm{Fe}_{2} \mathrm{O}_{3}+2 \mathrm{C}
$$

The exact form of carbon in this equation is speculative. However, the increase of $\mathrm{Fe}^{3+} / \Sigma \mathrm{Fe}$ in the ultramafic clasts is consistent with the observed increase of complex abiotic hydrocarbon phases in pore fluids from the most distal mud

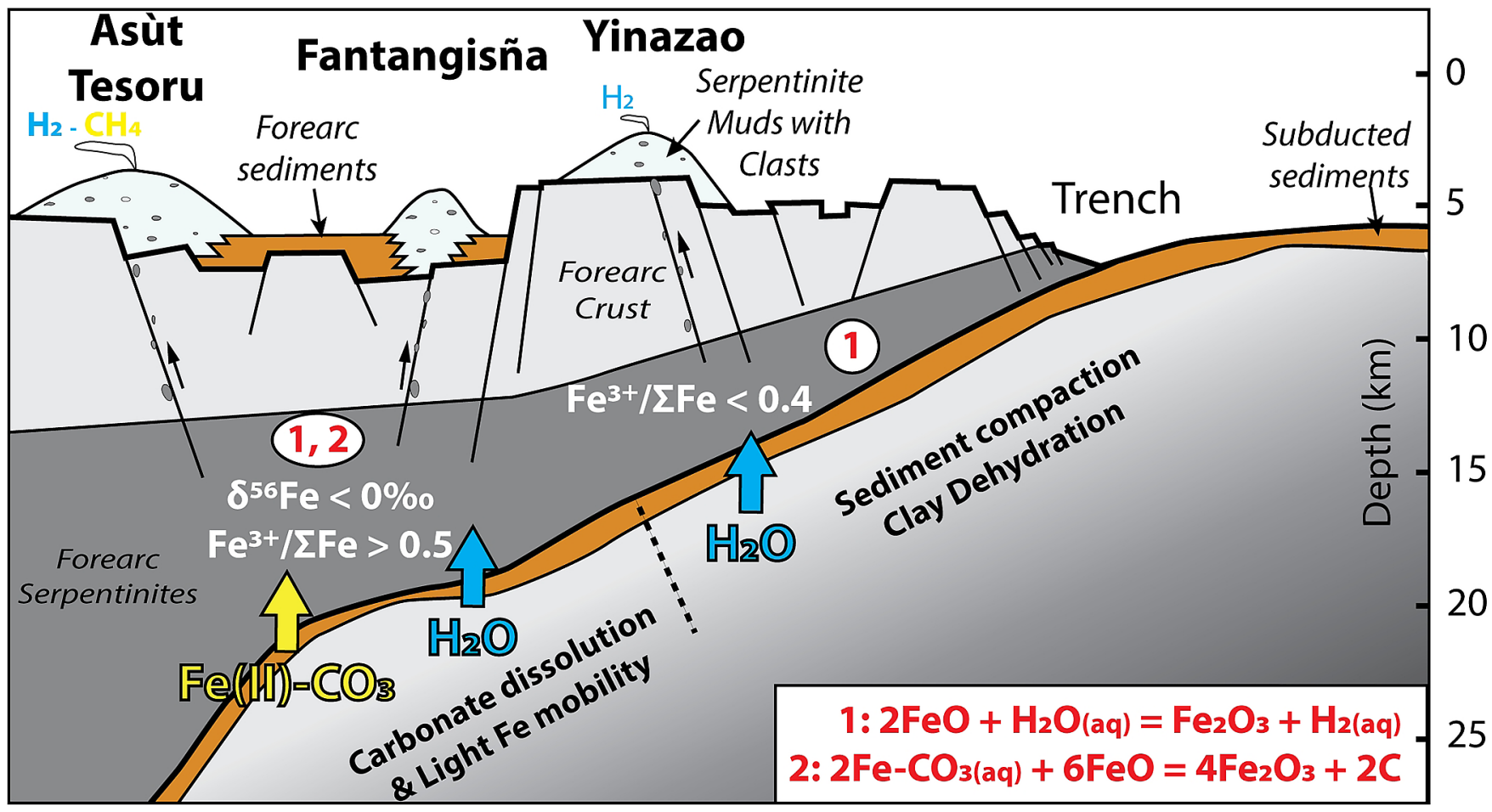

Increasing Distance from the trench

Figure 3 Cartoon illustrating redox and isotopic transfers between the slab and the forearc mantle wedge. 
volcanoes (Eickenbusch et al., 2019), suggesting that carbon may be the relevant oxidising agent in this setting. Furthermore, several studies have speculated the sulfate anions, derived from hydrous breakdown of sulfides, can complex with Fe and facilitate its transfer to the mantle wedge, for example:

$$
\mathrm{FeSO}_{4(\mathrm{aq})}+12 \mathrm{FeO}=4 \mathrm{Fe}_{3} \mathrm{O}_{4}+\mathrm{FeS}
$$

Reactions of this type are consistent with several studies which have shown that progressive prograde metamorphism of the subducting slab is associated with the release of sulfate- and/or carbonate-bearing fluids that mobilise light $\delta^{56} \mathrm{Fe}$ (Debret et al., 2016, 2018). The percolation of such fluids into the forearc can drive Fe oxidation and therefore explain the negative correlation between $\delta^{56} \mathrm{Fe}$ and $\mathrm{Fe}^{3+} / \Sigma \mathrm{Fe}$ (Fig. 2c), despite the absence of a correlation with bulk rock water contents (Fig. S-4).

The oxygen fugacity $\left(f \mathrm{O}_{2}\right)$ of slab-derived fluids is believed to increase with depth (e.g., Debret et al., 2016), with high $\mathrm{fO}_{2}$ conditions (e.g., magnetite/hematite buffer) occurring at eclogite facies conditions ( $80 \mathrm{~km}$ depth). Thus, during shallow forearc hydration (13-18 km depth), sulfur is expected to be equilibrated at modest $f \mathrm{O}_{2}$ in slab-derived fluids and mainly transferred under reduced form (e.g., $\mathrm{H}_{2} \mathrm{~S}$ ), while carbon will be equilibrated as an oxidised form $\left(\mathrm{CO}_{2}\right)$. It is thus plausible to consider that carbonate could be the main ligand transferring isotopically light Fe from the slab to the shallow mantle wedge. This is consistent with the high carbon concentrations measured in Mariana pore fluids from the most distant mud volcanoes (Fryer et al., 2018). Together, the correlation between Fe isotopes, FME concentrations and ratios, and iron redox state demonstrate a critical role for slab-derived fluids in regulating the redox state of the mantle wedge.

\section{Acknowledgements}

This research used samples and data provided by the IODP and ODP. We are grateful to the crew of the D/V JOIDES Resolution and to the science party of IODP Expedition 366. Funding for this research was provided by a NERC Moratorium Award (NE/P020860/1, to BD and HMW), the F.R.S.F.N.R.S. (BD), the Fondation Wiener Anspach (RG97553, NM, BD and HMW), the ERC Consolidator Grant (306655, HMW), a NERC Critical Minerals grant (NE/M010848/1, HMW) and a Schlanger Fellowship Award (IS). We thank K. Evans and F. Poitrasson for critical comments on earlier version of this article and careful editorial handling by $\mathrm{M}$. Boyet. This study contributes to the IdEx Universite de Paris ANR-18-IDEX-0001.

Editor: Maud Boyet

\section{Additional Information}

Supplementary Information accompanies this letter at http:// www.geochemicalperspectivesletters.org/article2003.

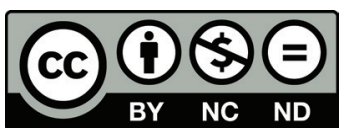

This work is distributed under the Creative Commons Attribution Non-Commercial No-Derivatives 4.0 License, which permits unrestricted distribution provided the original author and source are credited. The material may not be adapted (remixed, transformed or built upon) or used for commercial purposes without written permission from the author. Additional information is available at http://www.geochemicalperspectivesletters.org/ copyright-and-permissions.
Cite this letter as: Debret, B., Reekie, C.D.J., Mattielli, N., Beunon, H., Ménez, B., Savov, I.P., Williams, H.M. (2020) Redox transfer at subduction zones: insights from Fe isotopes in the Mariana forearc. Geochem. Persp. Let. 12, 46-51.

\section{References}

Bebout, G.E. (2013) Chemical and Isotopic Cycling in Subduction Zones. Treatise on Geochemistry: Second Edition 4, 703-747, doi: 10.1016/ B978-0-08-095975-7.00322-3.

Canil, D., O’Neill, H.S.C., Pearson, D.G., Rudnick, R.L. McDonough, W.F., Carswell, D.A. (1994) Ferric iron in peri dotites and mantle oxidation states. Earth and Planetary Science Letters 123, 205-220.

Craddock, P.R., WArRen, J.M., DAuphas, N. (2013) Abyssal peridotites reveal the near-chondritic Fe isotopic composition of the Earth. Earth and Planetary Science Letters 365, 63-76.

Debret, B., Millet, M.-A., Pons, M.-L., Boullhol, P., Inglis, E., Williams, H. (2016) Isotopic evidence for iron mobility during subduction. Geology 44, 215-218.

Debret, B., Bouilhol, P., Pons, M.L., Williams, H. (2018) Carbonate Transfer during the Onset of Slab Devolatilization: New Insights from Fe and Zn Stable Isotopes. Journal of Petrology 59, 1145-1166.

DEBRET, B. ET AL. (2019) Shallow forearc mantle dynamics and geochemistry: New insights from the IODP expedition 366. Lithos 326-327, 230-245.

Eickenbusch, P., Takai, K., Sissman, O., Suzuki, S., Menzies, C. (2019) Origin of Short-Chain Organic Acids in Serpentinite Mud Volcanoes of the Mariana Convergent Margin. Frontiers in Microbiology 10, 1-21.

Evans, B.W. (2004) The Serpentinite Multisystem Revisited: Chrysotile Is Metastable. International Geology Review 46, 479-506.

Evans, K.A. (2012) The redox budget of subduction zones. Earth-Science Reviews 113, 11-32.

Frost, B.R. BALlHaUs, C. (1998) Comment on " Constraints on the origin of the oxidation state of mantle overlying subduction zones: An example from Simcoe, Washington, USA"'. Geochimica et Cosmochimica Acta $62,329-331$.

Fryer, P., Wheat, C.G., Williams, T., Scientists Expedition, 366 (2018) Mariana Convergent Margin and South Chamorro Seamount. Proceedings of the International Ocean Discovery Program 366.

HuAnG, J., GuO, S., Jin, Q.-Z., HuAng, F. (2019) Iron and magnesium isotopic compositions of subduction-zone fluids and implications for arc volcanism. Geochimica et Cosmochimica Acta, doi: 10.1016/j. gca.2019.06.020

Kelley, K.A., Cottrell, E. (2009) Water and the oxidation state of subduction zone magmas. Science 325, 605-607.

LI, D.Y., XiaO, Y.L., LI, W.Y., ZHU, X., Williams, H.M., LI, Y.L. (2016) Iron isotopic systematics of UHP eclogites respond to oxidizing fluid during exhumation. Journal of Metamorphic Geology 34, 987-997.

Nebel, O., Sossi, P.A., Bénard, A., Wille, M., Vroon, P.Z., Arculus, R.J. (2015) Redox-variability and controls in subduction zones from an iron-isotope perspective. Earth and Planetary Science Letters 432, $142-151$.

NiU, Y. (2004) Bulk-rock major and trace element compositions of abyssal peridotites: Implications for mantle melting, melt extraction and postmelting processes beneath Mid-Ocean ridges. Journal of Petrology 45, 2423-2458

PARKInSON, I.J., PeARCE, J.A. (1998) Peridotites from the Izu-Bonin-Mariana forearc (ODP Leg 125): evidence for mantle melting and melt-mantle interaction in a supra-subduction zone setting. Journal of Petrology 39, 1577-1618.

Poitrasson, F., Delpech, G., Gregoire, M. (2013) On the iron isotope heterogeneity of lithospheric mantle xenoliths : implications for mantle metasomatism, the origin of basalts and the iron isotope composition of the Earth. Contributions to Mineralogy and Petrology 165, 1243-1258.

Polyakov, V.B., MineEV, S.D. (2000) The use of Mossbauer spectroscopy in stable isotope geochemistry. Geochimica et Cosmochimica Acta 64, 849-865.

SAVOV, I.P., RYAN, J.G., D'ANTONIO, M., FrYeR, P. (2007) Shallow slab fluid release across and along the Mariana arc-basin system: Insights from geochemistry of serpentinized peridotites from the Mariana fore arc. Journal of Geophysical Research: Solid Earth 112, B09205.

Schwartz, S., Gulllot, S., Reynard, B., Lafay, R., Debret, B., Nicollet, C., Lanari, P., Auzende, A.L. (2013) Pressure-temperature estimates of the lizardite/antigorite transition in high pressure serpentinites. Lithos 178, 197-210. 
Sossi, P.A., Halverson, G.P., Nebel, O., Eggins, S.M. (2015) Combined separation of $\mathrm{Cu}$, Fe and $\mathrm{Zn}$ from rock matrices and improved analytical protocols for stable isotope determination. Geostandards and Geoanalytical Research 39, 129-149.

Turner, S., Williams, H., Piazolo, S., Blichert-Toft, J., Gerdes, M., ADAM, J., LIU, X.M., SCHAEFER, B., MAURY, R. (2018) Sub-arc xenolith $\mathrm{Fe}-\mathrm{Li}-\mathrm{Pb}$ isotopes and textures tell tales of their journey through the mantle wedge and crust. Geology 46, 947-950.

Williams, H.M., McCammon, C.A., Peslier, A.H., Halliday, A.N., Teutsch, N., LeVasseur, S., BURG, J.P. (2004) Iron isotope fractionation and the oxygen fugacity of the mantle. Science 304, 1656-1659. 